\title{
Expert System for Decision Support Division of Inheritance According to Islamic Law
}

\author{
Adi Fitra Andikos, Gunawan Ali , Wulan Andang Purnomo
}

Department of Computer Science, Dharmas Indonesia University, Indonesia

\begin{tabular}{l}
\hline \hline Article Info \\
\hline Article history: \\
Received Jun 3, 2016 \\
Revised Aug 6, 2016 \\
Accepted August 22, 2016 \\
\hline
\end{tabular}

Keyword:

Decision support

Expert system

Legacy distribution

\begin{abstract}
Develop an expert system as supporting legacy property distribution of decision which based on the Islamic law. This expert system expected can help everyone who need distribution value of legacy property by using distribution method based on the Islamic law. The legacy property value which will be distributed is legacy property after taken by the will if it was. And debt, corpse of administration cost. The distribution result is an percentage value for each heir who have right to get the property legacy after distribution process. Determination of nominal value of legacy property will not be count in this system. The user system can obtain nominal value of distribution property by multiplying the distribution percentage with whole value of legacy property. The result that taken form this expert system is output as information of heir group who has right to the legacy, and percentage value for each heir who has right to get the legacy. The inference method that used in this expert system is Forward Chaining Method. The method that used for system analysis and designing is Data Flow Oriented method by using Data Flow Diagram (DFD) tool. The database design is using Entity-Relationship Diagram (E-R Diagram) relation model.
\end{abstract}

Copyright () 2016 Institute of Advanced Engineering and Science. All rights reserved.

Corresponding Author:

Adi Fitra Andikos,

Department of Computer Science,

Dharmas Indonesia University,

18 Koto Baru Road, Padang, West Sumatra, Indonesia County 27681.

Email: adifitra@undhari.ac.id

\section{INTRODUCTION}

The use of computers has evolved from mere data processing or presentation of information, being able to provide options as support decision making. This is made possible thanks to the existence of a hardware technology development, which is accompanied by the development of the software, as well as the capability of assembling and merging some of the techniques of decision-making in it [3]. The integration of hardware, software, and knowledge of an expert decision support system that allows users to perform faster decisionmaking and scrutiny. Computer-based decision support systems is a computer-based system designed to increase the effectiveness of the decision makers in solving problems. The techniques used for troubles hooting in case of using forward chaining [8].

The Division of inheritance often becomes a problem that occasionally sparked controversy and cause cracks family relationships. The main cause is human greed or avarice, and also because of the lack of knowledge of related parties about the Legal Division of the inheritance. In addition the limited experts or people who have the knowledge and expertise that can provide solutions to people who need information about the Division of inheritance in Islam.

One of the negative influences of globalization in public life is the occurrence of shift in lifestyles and viewpoints of the community on matters relating to Islam. Things related to Islam in some societie 
regarded as old-fashioned and outdated. Many people are allergic to Islamic rules defined by religion, including in terms of the Division of property inherited or faraid science. Because it led to the science of science becoming a faraid is rare, so when performing Division of Division of property in heritance of frequent confusion because of the knowledge which is less difficult to find a place to ask about it. At the time of entering the 21 st century, there is a major change to how managers use computerized support in decision making by using a decision support system. Decision support system (SPK) is used in as a tool for the decision to expand the capability of Wesel the Wesel decision, but not to substitute its assessment of the Wesel decision [8].

It looks clear that the use of computer-based information technology will greatly assist in the decision making process which is closely related to problem solving life today, then the author is interested in implementing the expert system to aid decision making the Division of the estate based on Islamic law by establishing expert system for decision support Division of Inheritance according to Islamic law.

\section{RESEARCH METHOD}

The image specified by the heirs of God explicitly in the Qur'an is the child, parents, husband or wife, brother se mom, and brother or half-brother was raised. But the scholars have established that there were fifteen men and ten women who are entitled to get the inheritance. In this case no one goes against the consensus of the scholars, because they rely on their evidence of the Qur'an and the Hadith of Prophet Muhammad and could be described as in the picture.

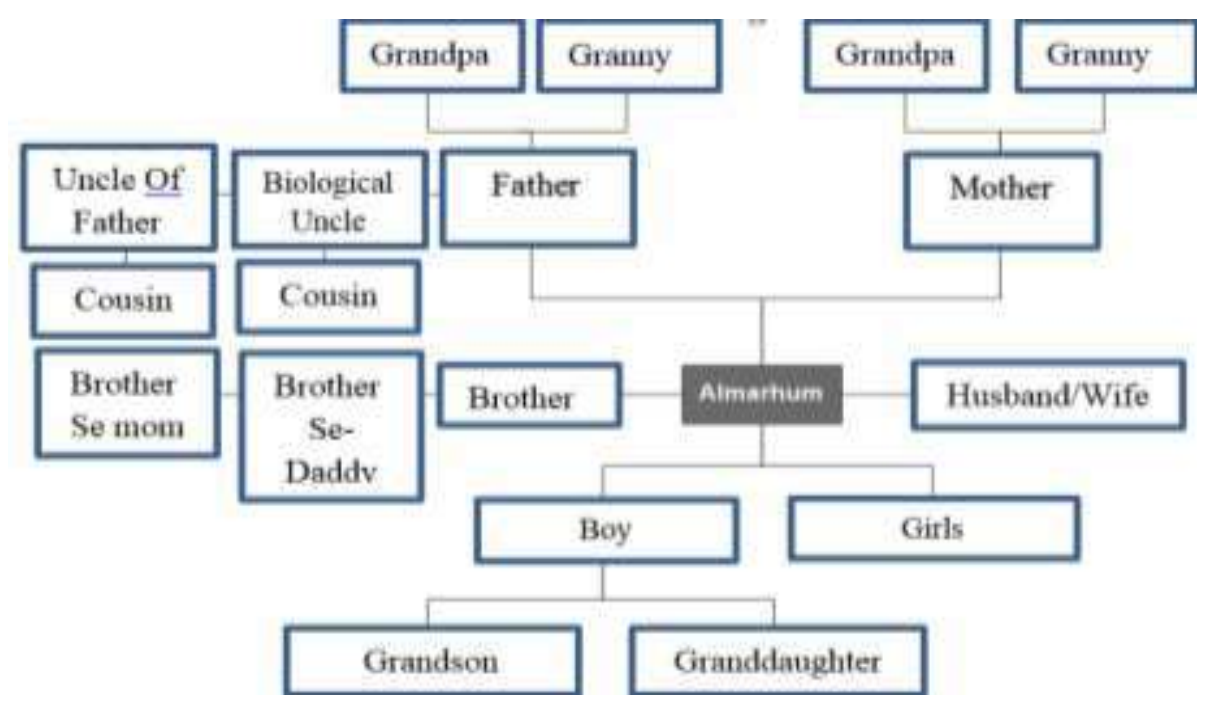

Figure 1. Diagram of the heirs

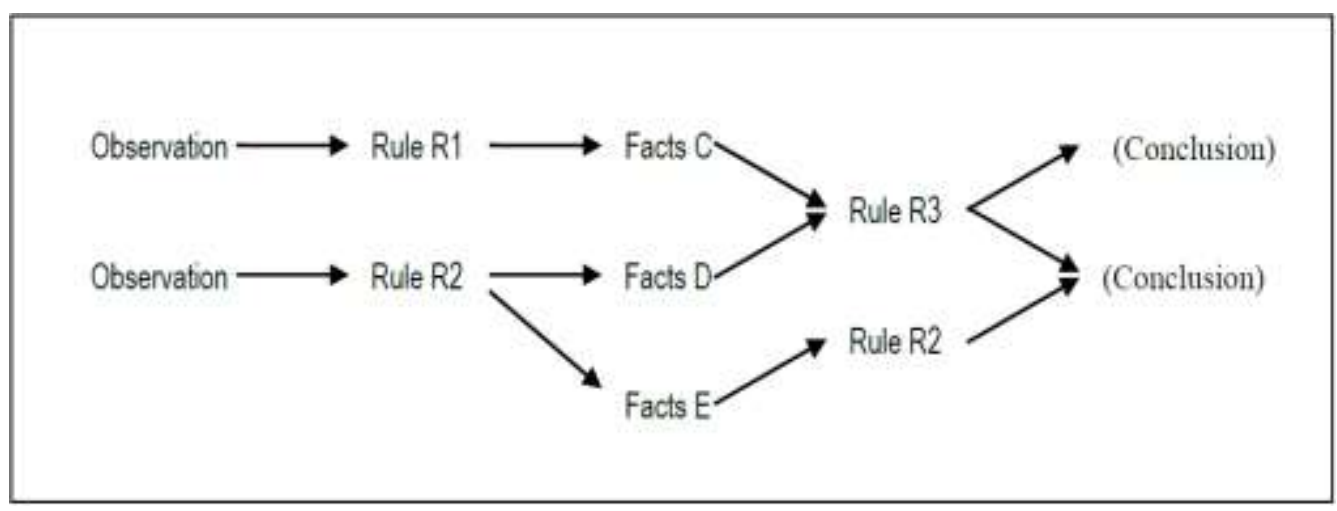

Figure 2. The process forward chaining [8] 


\section{RESULTS AND ANALYSIS}

\subsection{Decision Support System/DSS} namely:

Sprague and Carlson defines DSS pretty well, as the system has five main characteristics [7],

1. computer-based systems

2. Is used to help the decision makers

3. To solve complicated problems that are "impossible" is done by manual calculation

4. Through an interactive simulation

5. Where data and model analysis as the main component.

According to Keen and Scoot Morton, that decision support Systems are: Decision support system is a merger of the source of the intelligence of the individual components with the ability to improve the quality of decisions. Decision support system is also a computer-based information system for management decision making that deal with problems of semi structur.

In the sense of the above can be explained that the decision support system is not a decision making tool, but rather a system that helps decision makers by equipping them with information from data that has been processed with relevant and needed to make a decision about an issue more quickly and accurately. So the system is not intended to replace the decision-making in the process of decision making.

\subsection{Constituent Components Of The Decision Support System}

1. Data base management subsystem

2. Model Base Management Subsystem

3. Sub system Dialog

\subsection{Expert System}

Expert system is a computer program that uses artificial intelligentsia strategy as a symbolic representation, inference, and search a nerve [3], to perform tasks that can only be done by experts. Before explaining how to represent knowledge should first note the types of knowledge as this will affect the use of knowledge representation techniques. Type of knowledge according to John Durkin differentiated into five knowledge, namely Table 1 .

Table.1 Type of knowledge according to John Durkin differentiated into five knowledge

\begin{tabular}{|c|c|c|c|}
\hline No & Name & Consist of & Description \\
\hline 1 & $\begin{array}{l}\text { Procedural } \\
\text { Knowledge }\end{array}$ & $\begin{array}{l}\text { Rule } \\
\text { Strategy } \\
\text { Agenda } \\
\text { Procedure }\end{array}$ & $\begin{array}{l}\text { This knowledge outlines how the problem can be solved. This type has a goal } \\
\text { of how to do something. Rule, Strategy, agenda and procedure is a type of } \\
\text { procedural knowledge used in the expert system. }\end{array}$ \\
\hline 2 & $\begin{array}{l}\text { Declarative } \\
\text { Knowledge }\end{array}$ & $\begin{array}{l}\text { Concept } \\
\text { Object } \\
\text { Fact }\end{array}$ & $\begin{array}{l}\text { This knowledge explain what problems are known. This includes a simple } \\
\text { statement,which spelled out in the form of false (false) or true (true). }\end{array}$ \\
\hline 3 & $\begin{array}{l}\text { M e t a } \\
\text { Knowledge }\end{array}$ & $\begin{array}{l}\text { Knowledge } \\
\text { about other types of } \\
\text { knowledge. }\end{array}$ & $\begin{array}{l}\text { Knowledge which is used for basic understanding of the other. This type of } \\
\text { knowledge is used to taking other knowledge to solve a problem. }\end{array}$ \\
\hline 4 & $\begin{array}{l}\text { Heuristic } \\
\text { Knowledge }\end{array}$ & $\begin{array}{l}\text { Rules of } \\
\text { Thumb }\end{array}$ & $\begin{array}{l}\text { This knowledge is often called shallow knowledge precision and knowledg } \\
\text { representation is compiled by an expert through experience that has been } \\
\text { experienced by these scholars in the past. }\end{array}$ \\
\hline 5 & $\begin{array}{l}\text { Structural } \\
\text { Knowledge }\end{array}$ & $\begin{array}{l}\text { Rule Set, } \\
\text { Concept Relationship, } \\
\text { concept Object } \\
\text { Relationshitp }\end{array}$ & $\begin{array}{l}\text { This knowledge outlines the structure of knowledge. This type of knowledge } \\
\text { also model the problem faced by an expert. Model of the concept, the concept, } \\
\text { and the object is a tip from this knowledge }\end{array}$ \\
\hline
\end{tabular}

Faraid is the plural form of al-faridhah which means something that is required, or a division that has been determined in accordance with the respective simply applied Faraid science is the study of the calculation and the Division of property inheritance for each beneficiary based on Islamic jurisprudence. Tracking forward is driven approach data (data-driven). This approach starts from the tracking information input, and then try to describe the conclusions. Tracking ahead to make the facts in accordance with section if the rule if later. Figure 1 shows the process forward chaining. Runut inference methods forward (forward chaining) suitable to deal with the problem of controlling (controlling) and forecasting (prognosis) [5]. 


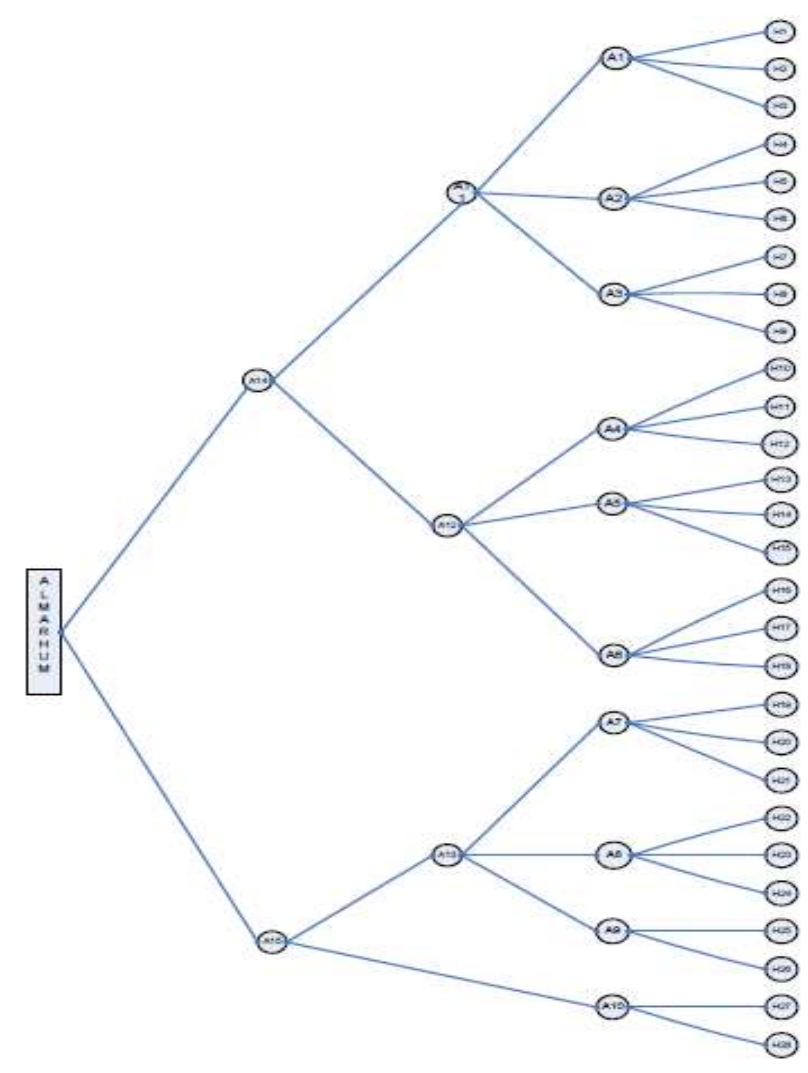

Figute 3. Reasoning The Decision Of The Division Of The Inheritance

To support the reasoning in the Division of inheritance according to Islamic law, then the knowledge gained from the experts can be represented in the form of a decision tree.

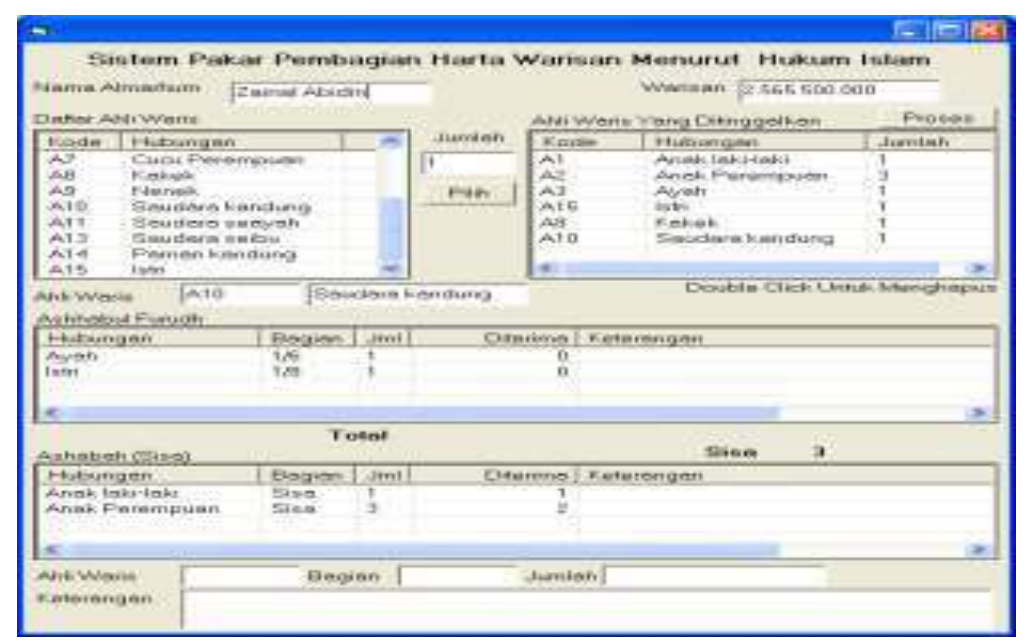

Figure 4. then the knowledge gained from the experts can be represented in the form of a decision tree.

\section{CONCLUSION}

The most important issue on expert system is a method of finding a decision. According to keen and scoot morton, that is a decision support system: a decision support system liquid pooling intelligence sources 
for the individual components with the ability to improve the quality of decisions. Decision support systems are also liquid computer-based information system for management decision making that deal with problems spring steel structure. Expert system is one method that could be used this way in decision-making. Method of forward-chaining inference is a strategy that starts with a set of facts, new facts are obtained by using a rule, which is the party that is used in accordance with the facts, and continue this process of fund objective sachieved or funds there is no further rules that have the appropriate parties with facts or the facts are known. The main advantage of this technique can be reasoning starts from the fact beforehand to test the truth of the hypothesis.

The techniques used in this inference is reasoning mechanism forward (forward chaining), that the rules are tested one by one. If his condition is true then that order is kept then the next rule is tested. Conversely, if conditions are wrong, it is not storedand the next rule is tested. With all the facts stored in the database, the input enters through the user interface will be processed with the program data into the desiredin ference as output.

Inference mechanism for calculating inheritance uses a search engine first bread. The search process is initiated by entering an existing heirs one by one, the heirs of the inputed will give true and will not be given a value of false. Subsequent search onthe rule and calculate the part to ashhabul furudh. Having obtained the results to ashhabul furudh then the rule will be read back to assign parts of ashabah that receives the rest of the estate.

Another problem in the development of the system leads to calculation of thoroughly good toward men as well as women's party. In system implementation should usethe competent experts, to make mistakes against the breaking of the case can be avoided as small as possible. Reproduce the reference with regard to fiqh, meaning that knowledge base and base rules more developed again by comparing the references with regard to these principles.

\section{ACKNOWLEDGEMENTS}

We would lime to thank all academic staff in our university for supporting us in each research projects specially this one.

\section{REFERENCES}

[1] Dean, Thomas, Allen, James, and Aloimonos, yiannis, "Artificial Intelligence: Theory andPractice", The Benjamin/Cumming Publishing Company, Inc., California, 1995.

[2] L. Dym, Clive \& E. Levitt, Raymond, "Knowledge Based Systems in Engineering", Mc. Graw-Hill,Singapore,1991.

[3] Buchanan, 1985, "Expert Systems For Experts”, John Wiley \& Sons Inc, England,1988.

[4] Onochie, S.N. (2008). "Tertiary Education and Youth Empowerment - Mass Media Challenges". In: POFSA Journal of Arts Science and Technology Oko. 11: 160-166.

[5] Giarattano and riley, 1994, "Book expert systems: principles and programming 2nd - pws publishing co". ISBN 0534937446.

[6] Sprague, R. H. and Carlson, E. D., (1982). Building effective decision support systems. EnglewoodCliffs, N.J., Prentice-Hall. ISBN 0-130-86215-0.

[7] Sprague, R. H. and Watson H. J., (1993). Decision support systems: putting theory into practice.Englewood Clifts, N.J., Prentice Hall.

[8] Turban, Efraim, Aronson, Jay, E., Liang and Ting-Peng, (2005). Decision Support SystemsandIntelligent Systems. International Edition, Edisi 7, New Jersey: Pearson Prentice-Hall Education International.

\section{BIOGRAPHIES OF AUTHORS}

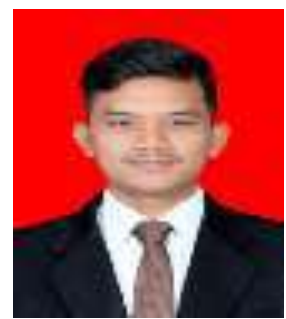

Adi Fitra Andikos his master degree computer science from Putra Indonesia University"Yptk" Padang Indonesia. Adi Fitra Andikos is an Assistant Expert and CS, Information Systems Department, Faculty of Computing and Information System, Dharmas Indonesia University. His a lecture di Information Systems Department, Faculty of Computing and Information System, Dharmas Indonesia University. His received his S.Kom in Computing and Information System from STMIK Dharmasraya College (Indonesia) in 2013. His research interests include: Data mining, Expert Sytem, Teknologi Database. 


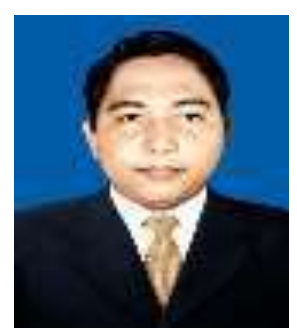

Gunawan Ali his master degree computer science from Putra Indonesia University"Yptk" Padang Indonesia. Gunawan is an Assistant Expert and CS, Information Systems Department, Faculty of Computing and Information System, Dharmas Indonesia University. His is lecture in Information Systems Department, Faculty of Computing and Information System, Dharmas Indonesia University. His received his S.Kom in Computing and Information System from Putra Indonesia University"Yptk" Padang Indonesia (Indonesia) in 2007. His research interests include: Decision support system, Knowledge Managemen System.

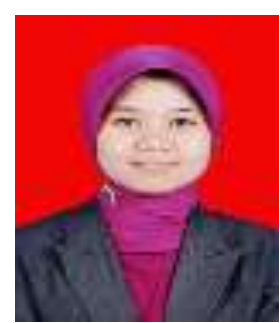

Wulan Andang P she master degree computer science from Putra Indonesia University"Yptk" Padang Indonesia. Wulan is an Assistant Expert and CS, Information Systems Department, Faculty of Computing and Information System, Dharmas Indonesia University. Wulan is lecture in Information Systems Department, Faculty of Computing and Information System, Dharmas Indonesia University. She is received his S.Kom in Computing and Information System from Putra Indonesia Bandung University (Indonesia) in 2010. She research interests include: Decision support system, Expert Sytem . 